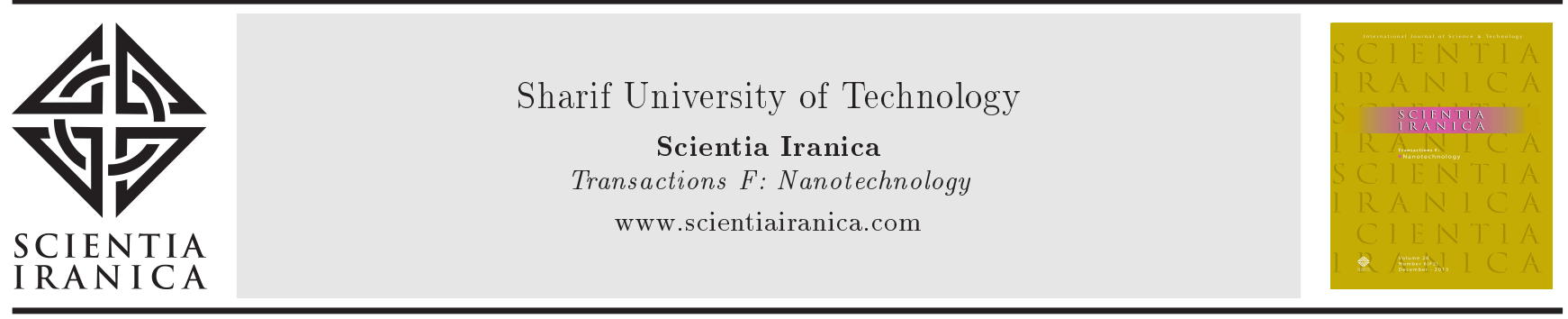

\title{
Evaluation of physical and mechanical properties of $\beta$-tri-calcium phosphate/poly-3-hydroxybutyrate nanocomposite scaffold for bone tissue engineering application
}

\author{
Sh. Shahi ${ }^{\mathrm{a}}$ and S. Karbasi ${ }^{\mathrm{b}, *}$ \\ a. Department of Material Engineering, Shahreza Branch, Islamic Azad University, Shahreza, Isfahan, Iran. \\ b. Biomaterials Group, Advance Medical Technology Department, Isfahan University of Medical Sciences, Isfahan, Iran.
}

Received 10 June 2016; received in revised form 7 December 2016; accepted 13 February 2017

\section{KEYWORDS}

Nano- $\beta$-tricalcium phosphate $(\beta-\mathrm{TCP})$;

Poly-3-

hydroxybutyrate

(P3HB);

Scaffold;

Tissue engineering.

\begin{abstract}
One of the major challenges facing researchers of tissue engineering is the scaffold design with desirable physical and mechanical properties for growth and proliferation of cells and tissue formation. In this paper, firstly, $\beta$-tricalcium phosphate $(\beta$-TCP) nanopowders with particle size of $50-70 \mathrm{~nm}$ were synthesized using a simple sol-gel route with calcium nitrate and potassium dihydrogenphosphate as calcium and phosphorus precursors, respectively. Then, the porous ceramic scaffold containing 40, 50, and $60 \mathrm{wt} \%$ of $\mathrm{n} \beta$-TCP was prepared by the polyurethane sponge replication method. The scaffolds were coated with P3HB for $30 \mathrm{sec}$ and $1 \mathrm{~min}$ in order to increase the scaffold's mechanical properties. XRD, XRF, SEM, TEM, and FT-IR were used in order to study the phase and element structure, morphology, particle size, and determination of functional groups, respectively. Based on the results of compressive strength and porosimetry tests, the most appropriate type of scaffold is $50 \mathrm{wt} \%$ of $\mathrm{n} \beta$-TCP immersed for $30 \mathrm{sec}$ in P3HB with $75 \%$ porosity in $200-600 \mu \mathrm{m}$, with a compressive strength of $1.09 \mathrm{MPa}$ and a compressive modulus of $33 \mathrm{MPa}$, which can be utilized in bone tissue engineering.
\end{abstract}

(C) 2017 Sharif University of Technology. All rights reserved.

\section{Introduction}

Every year, almost two million patients worldwide undergo bone grafting procedure to regenerate bone injuries due to accidents and automobile accidents, birth defect, diseases, and different cancers [1,2]. Autografts and allografts are the current strategies for filling bone defects, but each has several disadvantages leading to limited structural and functional recovery $[3,4]$. For example, there are significant drawbacks to the use of autologous bone, such as limited access and unsta-

*. Corresponding author. Tel.: +98 313 r92 24 59;

Fax: +98313668 8597

E-mail address: karbasi@med.mui.ac.ir (S. Karbasi) ble nature, hematoma, infection, increased operative time, blood loss, chronic donor site pain, and extra cost $[4,5]$. Allograft bone substitutes involve risks of immune rejection, or even lead to infectious disease transmission [6]. Synthetic bone filling materials can be prepared free of obstacles mentioned for autografts and allografts [7]. Synthetic bone filling materials have the aim of mimicking the physical and mechanical nature of native tissue and promoting osteoconduction for bone repair [3]. Then, the best strategy to treat bone injuries is the use of tissue en gineering [8]. The primary goal of Tissue Engineering (TE) is to produce functional substitutes for damaged or lost tissues [9]. So far, various three-dimensional (3D) scaffolds have been produced, and then populated with signaling molecules and cells 
to act as a temporary physical framework allowing new tissues to grow and reconstruct the damaged ones [10]. In other words, tissue function restoration needs a template, a scaffold, which will play the role of extracellular matrix in order to allow cells to attach, migrate, and duplicate tissue ingrowth until the new tissue is fully regenerated $[11,12]$. Bone tissue has a great potential for being restored to other body tissues [13]. Inherently, natural bone tissue is a composite of a collagenous hydrogel matrix consisting of about $33-43 \%$ apatite minerals, 32-44\% organics, and 15-25\% water on a volumetric basis [14,15], which is accountable for the remarkable strength and partial elasticity in bone tissue [16]. Moreover, hybrid structures, made of synthetic or naturally occurring ceramics and polymers, have taken advantage of this combination such as the strong compressive strength of ceramics as well as the flexibility of ductile polymers. This combination seems to be a promising choice, in particular for bone tissue engineering $[17,18]$. Therefore, the consequent strategy is to combine polymers and inorganic components, such as $\mathrm{CaPs}$, to construct scaffolds that meet the requirements desired for bone tissue engineering application [19]. Bone tissue engineering attempts to reconstruct and maintain the function of human bone tissues using the combination of cell biology, materials science, and engineering principles [8]. Both ceramic matrix and polymer matrix scaffolds have high porosity, bioactivity, biodegradability, and other physical and mechanical properties required for bone tissue engineering [20]. Ceramic matrix scaffolds have greater ability to bond directly to bone tissue compared to polymer matrix scaffolds. This means that ceramic matrix scaffolds are more bioactive than polymer matrix scaffolds and are, therefore, recommended for bone tissue engineering [20]. $\beta$-TCP $\left[\mathrm{Ca}_{3}\left(\mathrm{PO}_{4}\right)_{2}\right]$ and $\mathrm{HA}\left[\mathrm{Ca}_{10}\left(\mathrm{PO}_{4}\right)_{6}\right.$ $\left.(\mathrm{OH})_{2}\right]$ are similar to those found in human bone; therefore, they are the most commonly used ceramics in the biomedical fields $[21,22]$. Among these bioceramics, $\beta$ TCP and $\alpha$-TCP have been widely used instead of apatites for hard tissue restoration due to their excellent tissue biocompatible, biodegradable, and osteoconductive characteristics [6,23]. For example, a biodegradable and osteoconductive biocomposite made of $\beta$-TCP particles and gelatin was proposed [24]. This material was tested in vivo with good results without the need for a second surgical operation to remove the device after healing occurrence [6]. This property imparts significant advantage to $\beta$-TCP compared to other bioceramics, which are not resorbed and replaced by newformed bone tissues [25]. Therefore, $\beta$-TCP bioceramics are extensively used in bone filling substituted in the field of oral plastic surgery and bone tissue engineering scaffolds [25]. Based on previous studies, a desired scaffold for bone engineering should comply with a number of mechanical and physiological demands:
1. Biocompatibility to provide cell attachment, differentiation, and proliferation;

2. Osteoconduction and osteoprodution (inducing powerful bone bonding);

3. Biodegradability at a rate of matching the rate of new tissue formation;

4. Mechanical capability in order to enable mechanical strength in load bearing sites prior to reconstruction of new tissue;

5. Interconnected porous structure for cell infiltration, tissue ingrowth, and vascularization $[6,26,27]$.

Consequently, the optimal scaffold design and fabrication techniques must be able to create porous structures convenient for attaining the desired mechanical function and mass transport properties [28]. Polymer replication methods enable the scaffolds formation with uniform and adjustable porosity [2931]. The method has been developed due to its interconnected pores that are similar to cancellous bone [11]. However, since $\mathrm{CaPO}_{4}$ has a ceramic nature, they are brittle; therefore, biomedical applications of bare $\mathrm{CaPO}_{4}$ scaffolds for bone tissue reconstruction have been largely limited by their poor mechanical properties such as compression strength, compression module, and toughness [32]. Hence, $\mathrm{CaPO}_{4}$ scaffolds have been modified by introducing ductile polymer as a reinforcing phase in order to improve the mechanical properties and decrease their brittleness [13]. For example, collagen coated BCP ceramics were studied and the biocompatibility towards osteoblasts was found to increase upon coating with collagen [33]. This approach resulted in applications of conventional composite manufacturing techniques to the field of biomaterials, and the studies summarized showed that the proper combination of a brittle, hard and bioactive $\mathrm{CaPO}_{4}$ matrix with a ductile polymer coating offers many advantages of both for clinical applications [6]. Poly-3-hydroxybutyrate (P3HB) is a partially crystalline polymer with a high melting temperature and a high degree of crystallinity, which can be applied as a coating in ceramic scaffolds [8]. Poly3-hydroxybutyrate, as a member of the polyhydroxyalkanoate family, known as PHB, has attracted much attention for a wide range of medical applications due to its biodegradation, which indicates a much longer degradation time compared to polymers of the poly (ahydroxyacid) group [34,35]. Namely, PHB/carbonated ACP and PHBHV/carbonated ACP biocomposites appeared to be well suited as slowly biodegradable bone replacement material [36]. Kang et al. [37] showed that the compressive strength of $\beta$-TCP scaffolds increased from 2.90 to $4.19 \mathrm{MPa}$ using the infiltration of PLGA while retaining an interconnected porous structure with a porosity of $80 \%$. Miao et al. [38] produced scaffolds 
from HA/TCP coated with the polymer PLGA, and the compressive strengths of the scaffolds increased up to $660 \mathrm{kPa}$ by the PLGA incorporation in ceramicbased scaffolds. Foroughi et al. [20] indicated that HA scaffolds coating with poly-3-hydroxybutyrate, by and large, improved the compressive strength of the HA scaffolds. Their results exhibited porosity of $80-90 \%$ and compressive strength and modulus of 1.51 and 22 $\mathrm{MPa}$, respectively. Bang et al. [19] evidenced that the compressive strength of $\alpha$-TCP foam increased from 30 to $750 \mathrm{kPa}$ by modification with interpenetration and coating of PCL. Therefore, based on the result of studies, it is clear that covering ceramic scaffold with polymer layers is one of the best achievements for production of bone tissue engineering scaffolds.

To the best of our knowledge, this is the first report on the fabrication of scaffolds from nano- $\beta$ TCP coated with P3HB. N $\beta$-TCP powder was prepared using a sol-gel route, and porous scaffolds were produced using a polymer replication method. In order to improve mechanical properties, scaffolds were dipcoated with $\mathrm{P} 3 \mathrm{HB}$. Moreover, the physical and mechanical properties of nano $\beta$-tricalcium phosphate-poly-3hydroxybutyrate (n $\beta$-TCP $/ \mathrm{P} 3 \mathrm{HB}$ ) composite scaffolds were evaluated.

\section{Materials and methods}

\subsection{Preparation of ceramic $n \beta-T C P$ nanopowder}

Calcium nitrate tetrahydrate $\left(\mathrm{Ca} \quad\left(\mathrm{NO}_{3}\right)_{2} \cdot 4 \mathrm{H}_{2} \mathrm{O}\right)$ (CNT) (Junseichemicals Co., Ltd., S. Korea) and potassium dihydrogenphosphate $\left(\mathrm{KH}_{2} \mathrm{PO}_{4}\right)$ (KDP) (Kanto Chemical Co., Inc., Japan) were used as starting calcium and phosphorous precursors. Figure 1 shows the flow chart of the sol-gel preparation of $\beta$ -

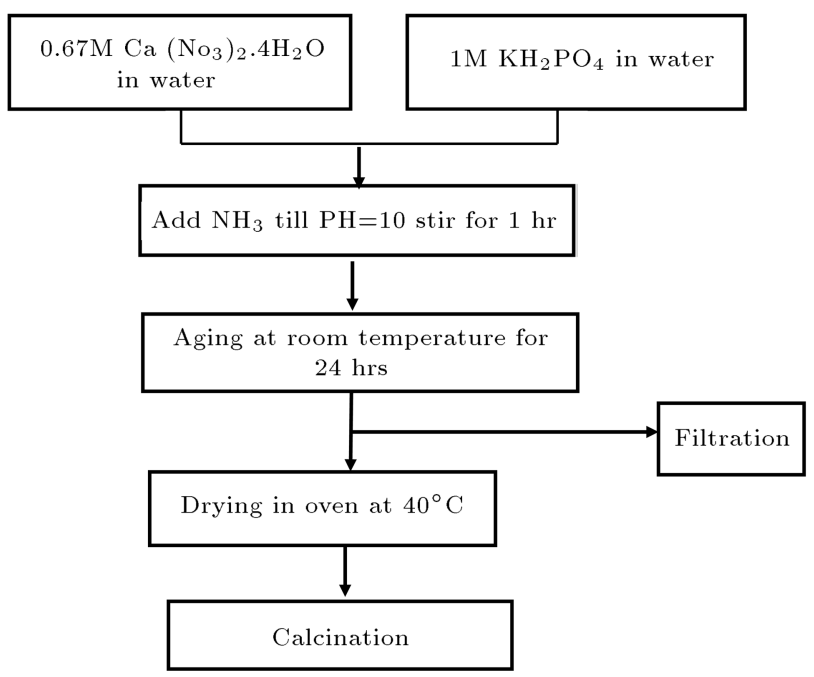

Figure 1. Flow chart of the sol-gel preparation of n $\beta$-TCP.
TCP. About $1 \mathrm{M}$ CNT and 0.67 M KDP solutions were prepared by dissolving the crystals in doubledistilled water. CNT solution was added drop-wise to the KDP solution while stirring. Ammonia $\left(\mathrm{NH}_{3}\right)$ (Daejung Chemicals and metals Co., Ltd., S. Korea) was added drop-wise to the above mixture resulting in white precipitation. The $\mathrm{NH}_{3}$ was added till the precipitation was complete, and the final $\mathrm{pH} 10$ was obtained. This precipitated solution was quickly stirred for $1 \mathrm{~h}$ and aged at room temperature for $48 \mathrm{~h}$. The precipitate was filtered and washed repeatedly using the vacuum pump via lukewarm distilled water to remove $\mathrm{NH}_{4}^{+}$and $\mathrm{NO}_{3}^{-}$ions. The created precipitate was dried at $40 \mathrm{C}$ for $24 \mathrm{~h}$ in a dry oven. This dried powder was calcined in air at $800^{\circ} \mathrm{C}$ for 30 min using an electrical furnace (Daesung electrics, Korea) and a heating rate of $10^{\circ} \mathrm{C} / \mathrm{min}$ [39]. Then, the powder produced was subjected to analysis by XRD, TEM, XRF, and FTIR tests.

\subsection{Fabrication of ceramic slurry}

Preparation of slurry stabilized with appropriate additives is significant and critical to scaffold fabrication; a variety of additives with a range of biological properties have been investigated [40]. In this study, $\beta$-TCP nanopowder with a particle size of $50-70 \mathrm{~nm}$ was utilized as the scaffold matrix. Then, $\mathrm{n} \beta$-TCP scaffold, containing various weight ratios of nano- $\beta$-tricalcium phosphate $(40,50$, and 60 wt. $\%$ ), was produced by a foam replication method. First, $\mathrm{n} \beta$-TCP powder (40, 50 and 60 wt.\%) was slowly dispersed in doubledistilled water to prevent agglomeration, and then the slurry was stirred at $350 \mathrm{rpm}$ for $90 \mathrm{~min}$ to obtain a homogeneous solution. To maximize the mechanical strength, large amounts of solid material should precipitate from the homogenized solution to the polyurethane sponge. Ammonium poly-methacrylate (DARVAN ${ }^{\circledR}$ C-N, R.T. Vanderbilt Company, Norwalk, USA) up to $4 \mathrm{wt} . \%$ was used as dispersant to obtain a uniform distribution of solid substance in the ceramic slurry in order to improve its rheological properties. Carboxymethyl cellulose (CMC, Hangzhou Hongbo Chemical Co. Ltd, China) powder (4 wt.\%) was gradually and slowly added to the solution in order to enhance slurry fluidity and prevent cracking of the struts during the subsequent heat-treatment process. The solution was stirred at $60^{\circ} \mathrm{C}$ until it was fully homogeneous.

\subsection{Preparation of porous scaffold}

A commercial polyurethane sponge (MEAY Co., Ltd. China; average pore size of $300-700 \mu \mathrm{m}$ ) was used in this research. Polyurethane sponge used as template that helped to manufacture ceramic cellular structures. The sponge was soaked into ceramic suspension and squeezed twice. Figure 2 shows the flow chart of the 


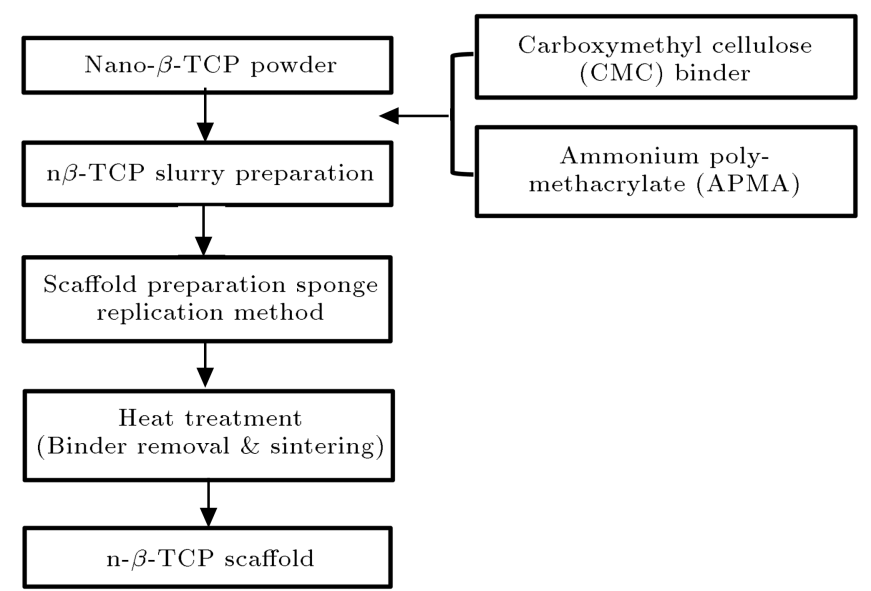

Figure 2. Flow chart of the polymer replication method used for the fabrication of $\mathrm{n} \beta$-TCP scaffolds.

polymer replication method used for the fabrication of $\mathrm{n} \beta$-TCP scaffold. This ensured that the ceramics coat the polyurethane walls to produce a replica of the reticulated foam material; the ceramic parts of the biomaterial infiltrated into the polymeric sponge pores [41]. The ceramic-coated polymeric template was dried for 24 hours at $80^{\circ} \mathrm{C}$ in an oven. Subsequently, the scaffolds were placed in a heat treatment furnace. $\mathrm{n} \beta$-TCP scaffold was formed in four stages:

1. Treatment at $600^{\circ} \mathrm{C}$ with a heating rate of $3^{\circ} \mathrm{C} / \mathrm{min}$;

2. Keeping at $600^{\circ} \mathrm{C}$ for 1 hour to completely burn the sponge;

3. An increase in temperature from 600 to $1260^{\circ} \mathrm{C}$ at a rate of $10^{\circ} \mathrm{C} / \mathrm{min}$;

4. Cooling to room temperature at a cooling rate of $10^{\circ} \mathrm{C} / \mathrm{min}$.

The cooled samples were removed from the furnace, measured, and then placed in desiccators. Figure 3 shows the diagram of heat treatment process of $n \beta$ TCP porous scaffold. In Figure 4, the left sponge shows the polyurethane sponge prior to immersion in ceramic slurry, and the right scaffold shows the ceramic scaffold produced at $1260^{\circ} \mathrm{C}$.

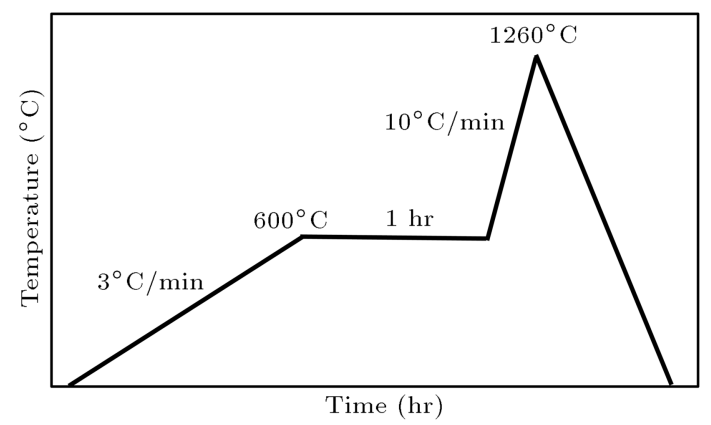

Figure 3. The diagram of heat treatment process of $\mathrm{n} \beta$-TCP porous scaffold.

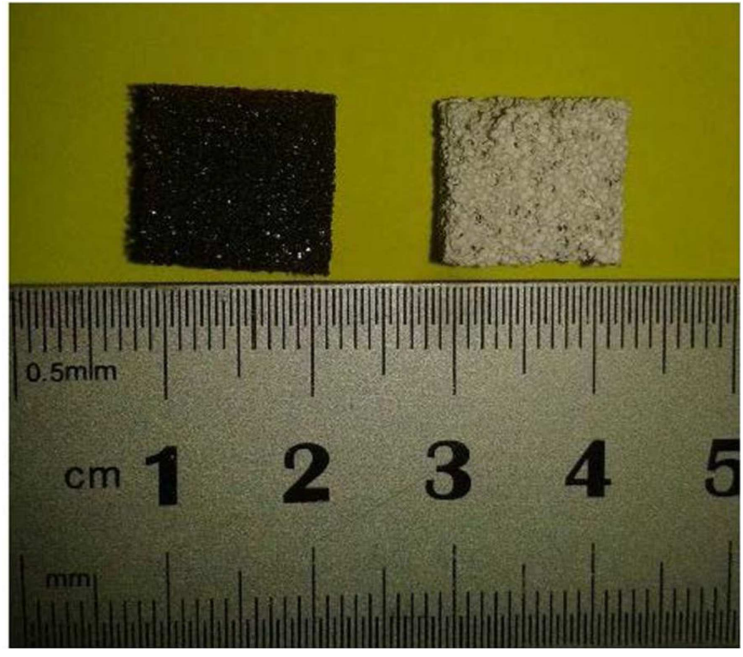

Figure 4. The left sponge showing the polyurethane sponge before immersion in ceramic slurry and the right scaffold showing the ceramic scaffold formed at $1260^{\circ} \mathrm{C}$.

\section{4. $n \beta-T C P$ scaffold coated with $Р$ РНВ}

One possible drawback of the method is the tendency to produce a hole in the center of each strut resulting from the removal of the polymer structure on heating. The presence of this hole can detrimentally affect the mechanical behavior of the scaffolds [42]. Therefore, the approach of filling the hole with a polymer leads to enhanced mechanical properties exploiting the interaction between the polymer and ceramics phases. In this research, $0.6 \mathrm{~g}$ of $\mathrm{P} 3 \mathrm{HB}$ powder (Sigma-Aldrich, St Louis, MO, USA) was dissolved and heated in $10 \mathrm{~mL}$ of chloroform (Sigma-Aldrich, USA) for 6 hours in an oil bath with a reflux condenser at $60^{\circ} \mathrm{C}$ to obtain the polymer solution for coating $\mathrm{n} \beta$-TCP scaffolds. Next, $\mathrm{n} \beta$-TCP scaffolds were immersed in the polymer solution for $30 \mathrm{sec}$ and $1 \mathrm{~min}$. To achieve a uniformly coated surface and remove excess polymer solution, the samples were wrapped in aluminum foils and centrifuged at $500 \mathrm{rpm}$ for $30 \mathrm{sec}$. Finally, the samples were placed in a vacuum oven at room temperature for $24 \mathrm{~h}$.

\subsection{Physical characterization}

\subsubsection{Thermal Gravimetric Analysis (TGA)}

Thermal Gravimetric Analysis (TGA) measures thermal stability and compounding materials. In this research, a thermal gravimetric analysis device (TG/DTA, TGA 401, Sanatara Co.) was used to record the decrease of weight percentage of the polyurethane sponge versus temperature. The sample was heated at a rate of $1^{\circ} \mathrm{C} / \mathrm{min}$ up to $600^{\circ} \mathrm{C}$ under nitrogen flow.

\subsubsection{XRF analysis}

$\mathrm{XRF}$ analysis was applied as chemical analysis and for determination of chemical composition of $\mathrm{n} \beta$-TCP powder. Elements with low atomic weight $(\mathrm{H} 2, \mathrm{He}$ and 
Li) cannot be identified with XRF; however, all the other elements can be identified.

\subsubsection{Transmission Electron Microscopy (TEM)}

Transmission electron microscopy (TEM, Philips CM200 FEG, Netherlands) was used to elucidate the morphology and particle size of $\beta$-TCP powders.

\subsubsection{X-ray diffraction analysis}

X-ray diffraction methods (XRD, Philips X'Pert) were applied to gain information about the structural changes and phases of $n \beta$-TCP powder, P3HB powder, $\mathrm{n} \beta$-TCP scaffolds with and without P3HB coating. $\mathrm{CuK} \mathrm{X}$-ray was used for the analysis. The scan rate was set to $1^{\circ} / \mathrm{min}$; the imposed voltage and current were $40 \mathrm{kV}$ and $30 \mathrm{~mA}$, respectively, and the diffraction angle $(2 \theta)$ varied from 10 to $90^{\circ}$ at a rate of $0.4^{\circ} / \mathrm{min}$.

\subsubsection{FT-IR spectroscopy}

Fourier transform infrared spectroscopy (FT-IR: 6300, JASCO, Japan) was used for studying the functional groups. Solid samples were prepared by pellet technique. This technique is based on the fact that a sample in $\mathrm{KBr}$ powder can be compressed under pressure with or without vacuum to fabricate transparent disks. Spectral analyses were performed using standard Nicolet and Microcal Origin software. FT-IR spectra were taken from $\mathrm{n} \beta$-TCP powder, P3HB powder, $\mathrm{n} \beta$ TCP scaffolds with and without P3HB coating.

\subsubsection{Scanning Electron Microscopy (SEM)}

Scanning electron microscopy (SEM, Philips XL-30, Netherlands) was applied to study the morphology of $\mathrm{n} \beta$-TCP scaffolds with and without $\mathrm{P} 3 \mathrm{HB}$ coat. The samples were coated with gold under an argon atmosphere.

\subsubsection{Porosity and density measurements}

Liquid displacement was used to calculate the porosity and density of the scaffolds. Scaffold density provides information about the size, distribution, and permeability of pores and the presence of structural defects in sintered ceramic frameworks [13].

Owing to the hydrophobic properties of the polymer, $96 \%$ ethanol, which can pass easily through pores, was used instead of water. The mass of the ceramic sample $(W)$ was measured, and a volume $\left(V_{1}\right)$ of ethanol was poured into a graduated cylinder and measured. The sample was immersed in ethanol for 5 min until it became saturated $\left(V_{2}\right)$. The difference between volumes $\left(V_{2}-V_{1}\right)$ represented the volume of the scaffold. The ethanol-soaked scaffold was removed from the graduated cylinder, and the remaining volume was recorded as $V_{3} . V_{1}-V_{3}$ represented the volume of ethanol absorbed by the scaffold [40].

The following equation calculates the density of scaffold $(\rho)($ Eq. (1)):

$$
\rho=\frac{W}{V_{2}-V_{3}} \text {. }
$$

The following equation calculates the amount of open porosity of scaffold $(\varepsilon)$ :

$$
\varepsilon=\frac{V_{1}-V_{3}}{V_{2}-V_{3}} .
$$

\subsection{Mechanical characterization}

Machining and gripping the specimen is a major problem in the mechanical characterization of porous ceramic structures; conventional methods of mechanical characterization, such as tensile, biaxial, and impact tests, are usually inapplicable to biomaterial with porous frameworks [13]. Compression impact tests for porous bone and $\mathrm{n} \beta$-TCP specimens with cellular structure are instead applied $[13,40]$. Compressive strength and compressive modulus tests for $\mathrm{n} \beta$-TCP scaffolds with and without $\mathrm{P} 3 \mathrm{HB}$ were measured using a compression impact tester (SANTAM- Eng. Design Co. LTD.) with a 10-KN load cell based upon guidelines set in ASTM-D5024-95a. The dimensions of each sample were $20 \times 10 \times 10 \mathrm{~mm}^{3}$ for the compression test. As ceramic scaffolds are fragile, the crosshead speed was set at $0.5 \mathrm{~mm} / \mathrm{min}$ to avoid any damage to the ceramic structure. The elastic modulus was calculated as the slope of the primary linear portion of the stressstrain curve. The yield strength was calculated from the intersection of the two tangents on the curve around the yield point.

\subsubsection{Statistical analysis for mechanical characterization}

Statistical analysis was carried out by two-way ONAVA analysis test in IBM SPSS 722 software.

\section{Results and discussion}

\subsection{XRF analyses of $\beta-T C P$ nanopowder}

The results of XRF analysis of $n \beta$-TCP powder sample produced using the sol-gel method are presented in Table 1, indicating, with acceptable matching, that the weight percentages are similar to standard weight percentages of $\mathrm{n} \beta$-TCP. The calculations showed that $\frac{\% W / W_{c a o}}{\% W / W_{p 2 o 5}}$ value is equal to 1.16 , remarkably close to theoretic value of 1.18 . These results verified the production of $n \beta$-TCP with desired weight percentages and excellent purity.

\subsection{TEM analyses of $\beta-T C P$ nanopowder}

Figure 5 displays TEM micrographs of $\mathrm{n} \beta$-TCP powder. Morphology and size of $\mathrm{n} \beta$-TCP particle are shown in the image. The particle-size distribution of $\mathrm{n} \beta$-TCP was mainly in the wide range of $50-70 \mathrm{~nm}$ with irregular particle shapes. 
Table 1. Chemical analysis of nano- $\beta$-TCP powder.

\begin{tabular}{cc}
\hline Compound & $\begin{array}{c}\text { Concentration } \\
(\% \mathbf{W} / \mathbf{W})\end{array}$ \\
\hline $\mathrm{CaO}$ & 51.1 \\
$\mathrm{P}_{2} \mathrm{O}_{5}$ & 43.89 \\
$\mathrm{Na}_{2} \mathrm{O}$ & 1.07 \\
$\mathrm{SO}_{3}$ & 0.972 \\
$\mathrm{MgO}$ & 0.852 \\
$\mathrm{SiO}_{2}$ & 0.625 \\
$\mathrm{Cl}$ & 0.416 \\
$\mathrm{H}_{2} \mathrm{O}$ & 0.399 \\
$\mathrm{Al}_{2} \mathrm{O}_{3}$ & 0.18 \\
$\mathrm{SrO}$ & 0.149 \\
$\mathrm{~K}_{2} \mathrm{O}$ & 0.18 \\
$\mathrm{Fe}_{2} \mathrm{O}_{3}$ & 0.069 \\
$\mathrm{CuO}$ & 0.037 \\
$\mathrm{ZnO}$ & 0.033 \\
$\mathrm{TiO}_{2}$ & 0.027 \\
$\mathrm{LOI}$ & \\
$\mathrm{Total}^{*}$ & 100 \\
\hline
\end{tabular}

${ }^{*}$ LOI: Loss On Ignition $\left(1400^{\circ} \mathrm{C}, 90 \mathrm{~min}\right)$.

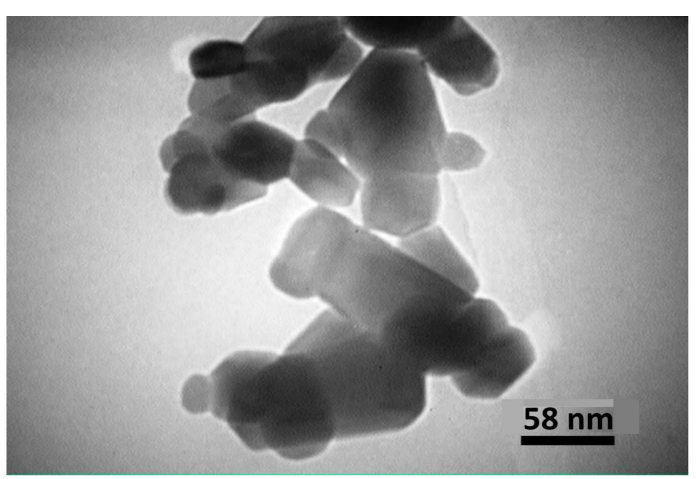

Figure 5. TEM of nano- $\beta$-TCP powder.

\subsection{XRD and FTIR analyses of $\beta-T C P$ nanopowder and $n \beta-T C P$ scaffold without РЗНB}

3.3.1. X-ray diffraction analysis

Figure $6(\mathrm{a})$ shows $\mathrm{X}$-ray diffraction spectra that $\mathrm{n} \beta$ TCP powder produced by the route of Sanosh et al. [39]. According to XRD spectra, it is obvious that the obtained product was $\mathrm{n} \beta$-TCP with high purity, and no additional stable phase was revealed. Diffraction peaks for the obtained product favorably corresponded to the standard JCPDS: 9-169 [43]. $\beta$ TCP crystallizes in the rhombohedral space group R3c with unit cell parameters $a=10.439 \AA, c=$ $37.375 \AA$ [44]. $\beta$-TCP crystal size at $800^{\circ} \mathrm{C}$ was estimated up to $38.50 \mathrm{~nm}$ by modified Scherer equation (Monshi et al.) [45]. It should be noted that besides

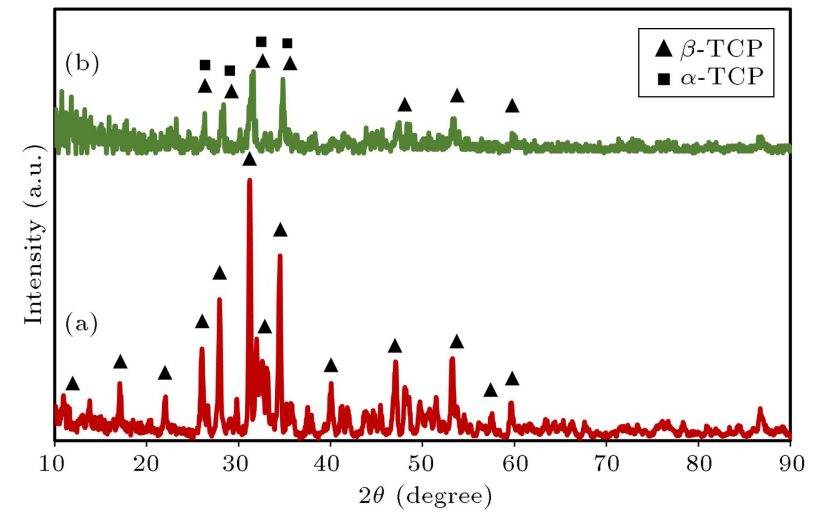

Figure 6. Pattern of XRD analysis: (a) n $\beta$-TCP powder; and (b) $\mathrm{n} \beta$-TCP scaffold sintered at $1260^{\circ} \mathrm{C}$.

finite crystallite size, deviations from ideal crystallinity has also a significant influence on revealing XRD peak broadening [39]. During calcination of $\mathrm{n} \beta$-TCP at $800^{\circ} \mathrm{C}$, crystallinity increases to more than $90 \%$ due to its predominating factor in sharping of the diffraction peaks rather than particle size; therefore, no overlaps appeared [39]. Then, by forming a solution and constructing scaffold at $1260^{\circ} \mathrm{C}$, peak XRDs are shown in Figure 6(b). XRD peaks of diffraction pattern agree appropriately with those standards of $\beta$-TCP phase in the diffraction file (Card No. 09-0169) as the primary crystalline phase and with a minor quantity of other phase as the secondary phase [43]. On the other hand, as evidenced by Gao et al. [43], $\beta$-TCP started being transformed to $\alpha$-TCP above $1180^{\circ} \mathrm{C}$. Hence, it is not surprising that the peaks associated with the conversion of $\beta$-TCP phase into $\alpha$-TCP phase appeared during sintering of $\beta$-TCP scaffolds at temperature up to $1260^{\circ} \mathrm{C}$. Therefore, the diffraction peaks at $28.30^{\circ}, 31.24^{\circ}$, and $34.60^{\circ}$ angles related to $\alpha$-TCP crystalline phase overlapped with several peaks of $\beta$-TCP crystalline phase, and acceptable matching was observed with the standard JCPDS: 9348 [43]. Furthermore, according to comparison of Figure 6(a) and (b) at a defined angle of $47^{\circ}$ concerning single-phase $\beta$-TCP at both patterns, $\beta$-TCP phase's quantitative values of both patterns related to powders and sintered scaffolds were determined by using the ratio of slopes method [46]. Based on the result of quantitative phase analysis, the quantitative value of $\beta$-TCP phase decreased. This indicates the fact that $\beta$-TCP phase has been converted into $\alpha$-TCP phase during sintering of $\beta$-TCP porous scaffolds above the transformation temperature of $1120^{\circ} \mathrm{C}$.

\subsubsection{FT-IR spectroscopy}

The patterns of FT-IR $\beta$-TCP powder and $\beta$-TCP ceramic porous scaffold are shown in Figure $7(\mathrm{a})$ and (b), respectively. Figure $7(\mathrm{a})$ shows FTIR diagram related to $\beta$-TCP powder, in which strong peaks at 1092 and $1040 \mathrm{~cm}^{-1}$ are typically related to the 


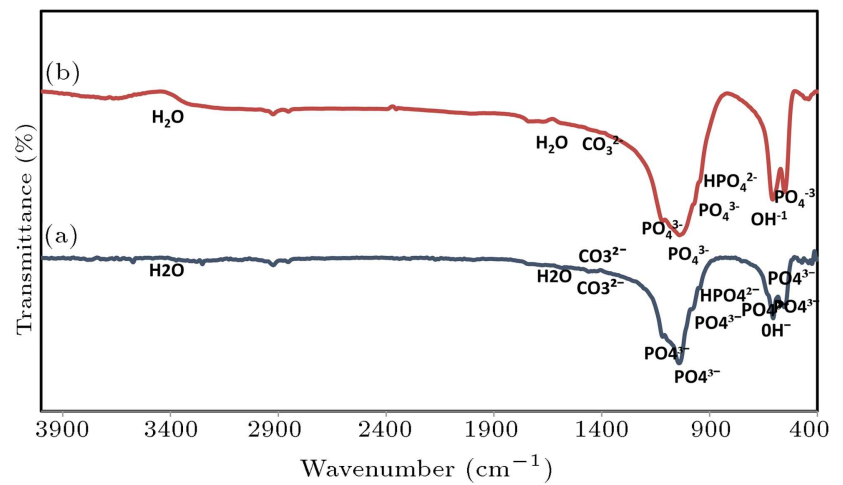

Figure 7. Pattern of FT-IR analysis: (a) n $\beta$-TCP powder and (b) porous ceramic scaffold of heat treatment at $1260^{\circ} \mathrm{C}$.

components of triply degenerate anti-symmetric P-O stretching $\nu_{3}$ vibration. Peripheral absorption band at $962 \mathrm{~cm}^{-1}$ is related to $\nu_{1}$, the non-degenerate $\mathrm{P}-\mathrm{O}$ symmetric vibration. 601 and $571 \mathrm{~cm}^{-1}$ bands in the spectra of $\mathrm{n} \beta$-TCP powder are related to components of triply degenerate $\nu_{4} \mathrm{O}-\mathrm{P}-\mathrm{O}$ bending vibration. The peaks visible at 1640 and $3400 \mathrm{~cm}^{-1}$ are also attributed to the molecular and absorbed water. The clear absorption bands at $632 \mathrm{~cm}^{-1}$ are attributed to the stretching and vibration of the significant concentration of hydroxyl group remaining in structure [39]. A weak peak emerged near $875 \mathrm{~cm}^{-1}$ is attributed to the stretching vibration of $\mathrm{P}-\mathrm{O}(\mathrm{H})$ band in $\mathrm{HPO}_{4}^{2-}$ groups. The short peaks observed near 1490 and $1426 \mathrm{~cm}^{-1}$ are due to $\nu_{3}$ vibration mode of $\mathrm{CO}_{3}^{2-}$ groups. The defined bands from inorganic carbonate ion indicate that carbon of furnace atmosphere gets dissolved in the organic components and does not pyrolyze completely and may instead dissolve into $\beta$ TCP crystal [39]. The mineral phase of bone consists of carbonates [47]; hence, $\beta$-TCP may tend to have better bioactivity as a consequence of $\mathrm{CO}_{3}^{2-}$ presence. The other peaks detected in Figure 7(b) reveal the same process mentioned in Figure $7(\mathrm{a})$.

\subsection{XRD and FTIR analyses of $n \beta-T C P$ scaffold with and without $P 3 \mathrm{HB}$ \\ 3.4.1. Thermal Gravimetric Analysis (TGA) of polymer foam}

In order to prevent cracks in the ceramic structure, there should be sufficient time for burning polymeric foams. Figure 8 shows the weight change of the polyurethane foam relative to temperature. TGA curve demonstrated that the polymer sponge would undergo weight decline in several stages, shown in the figure. The main part of the polymer was removed at temperatures between $380^{\circ} \mathrm{C}$ and $600^{\circ} \mathrm{C}$; therefore, it is necessary to take into account the slow heating rate at this stage to prevent structural damage caused by emissions from thermal degradation of polymers. At temperatures above $600^{\circ} \mathrm{C}$, the polymer foam had a low

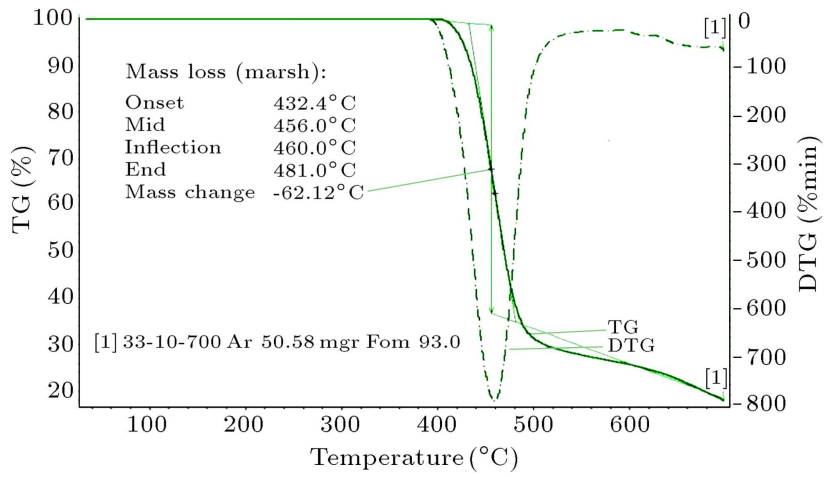

Figure 8. Weight loss as a function of temperature (heating rate $=3{ }^{\circ} \mathrm{C} / \mathrm{min}$ ) for pyrolysis of polyurethane sponge.

weight decrease due to the amount of carbon produced from the decomposition of the polymer process dioxide. Complete combustion of polymeric foams occurred at $600^{\circ} \mathrm{C}$.

\subsubsection{X-ray diffraction analysis}

Figure $9(\mathrm{a})$, (b), and (c) show X-ray diffraction patterns of $\mathrm{n} \beta$-TCP, P3HB, and $\mathrm{n} \beta$-TCP/P3HB scaffolds, respectively. The pattern of XRD in Figure 9(a) demonstrates the process mentioned in Section 3.1.1 about XRD of $\mathrm{n} \beta$-TCP porous scaffold. In Figure $9(\mathrm{~b})$, the main peaks of P3HB are detected, and Figure $9(\mathrm{c})$ is attributed to XRD pattern of $\mathrm{n} \beta$-TCP scaffold coated with P3HB; according to the standards of JCPDS: 009-0169 and JCPDS: 009-0348, the peaks of 13.86, 17.30, and 21.88 angles appeared in Figure 9(c) are assigned to P3HB. Since two of the strong peaks of P3HB are observed in Figure 9(c), it can be evidenced that the composite structure was a hybrid scaffold of $\mathrm{n} \beta$-TCP/P3HB.

\subsubsection{FT-IR spectroscopy}

The patterns of FTIR $n \beta$-TCP scaffold and P3HB pure polymer and $\mathrm{n} \beta$-TCP/P3HB scaffolds are shown in Figure 10(a), (b), and (c), respectively. The pat-

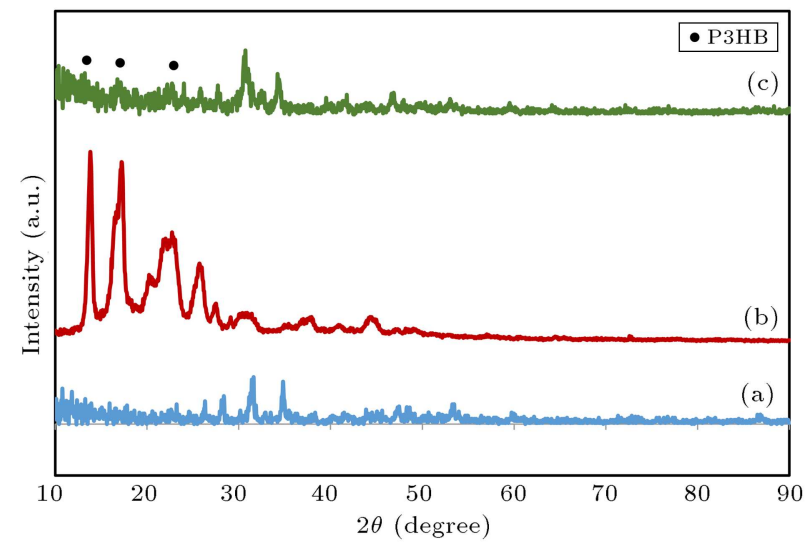

Figure 9. Pattern of XRD analysis: (a) n $\beta$-TCP scaffold, (b) P3HB, and (c) n $\beta$-TCP/P3HB scaffold. 


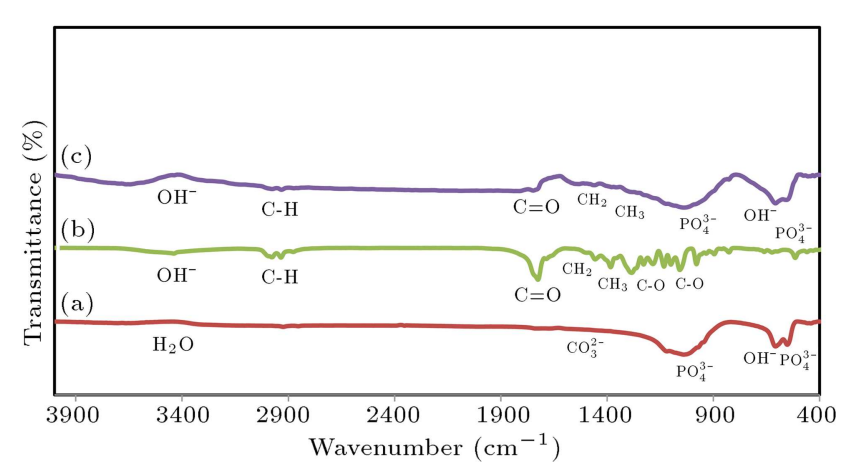

Figure 10. Pattern of FT-IR analysis: (a) $n \beta-T C P$ scaffold, (b) P3HB, and (c) n $\beta$-TCP/P3HB scaffold.

tern of FTIR in Figure 10(a) illustrates the process mentioned in Section 3.3.2 about FTIR of $\mathrm{n} \beta$-TCP scaffold. Figure 10(b) indicates FTIR diagram related to the P3HB, in which peaks of $1057,1132,1188$, and $1284 \mathrm{~cm}^{-1}$ are related to the stretching vibrations of C-O-C bond. A sharp peak centered at the wavelength of $1383 \mathrm{~cm}^{-1}$ is due to bending vibrations of CH3 group. The clear peak located at wavelength $1455 \mathrm{~cm}^{-1}$ is attributed to $\mathrm{CH}_{2}$ groups. The most intense peak visible at $1725 \mathrm{~cm}^{-1}$ belongs to stretching vibration of carbonyl $(\mathrm{C}=\mathrm{O})$ groups. The broad twin peak observed in the in-between range of 2874 and $2972 \mathrm{~cm}^{-1}$ is assigned to stretching aliphatic band of C-H. P3HB has terminal hydroxyl groups that can be observed at the relevant peak within a range of $3100-$ $3680 \mathrm{~cm}^{-1}$. Figure 10(c) shows FTIR diagram related to $\mathrm{n} \beta$-TCP/P3HB hybrid scaffold. In this diagram, all of the main and strong peaks originated from $\mathrm{P} 3 \mathrm{HB}$ polymer and $\mathrm{n} \beta$-TCP scaffold are observed in spectrum of $\mathrm{n} \beta$-TCP/P3HB scaffold. A short and clear peak composed at $1721 \mathrm{~cm}^{-1}$ corresponds to stretching mode of carbonyl $(\mathrm{C}=\mathrm{O})$ groups, and the absorption bands emerging at $2934-2972 \mathrm{~cm}^{-1}$ are assigned to stretching mode of $\mathrm{C}-\mathrm{H}$ aliphatic band. This shows that the scaffold produced has a hybrid composite structure of $\mathrm{n} \beta$-TCP/P3HB. In order to accurately evaluate the interaction of $\mathrm{n} \beta$-TCP and P3HB, FTIR spectra of the composite compared to unmodified $\mathrm{n} \beta$ TCP from 500 to $1140 \mathrm{~cm}^{-1}$ and FT-IR spectra of the composite compared to pure polymer from 1600 to $3000 \mathrm{~cm}^{-1}$ are shown in Figure 11 . Comparison of peaks belonging to $\mathrm{PO}_{4}^{3-}$ in both states of stretching and bending vibration in the region between $500 \mathrm{~cm}^{-1}$ and $1100 \mathrm{~cm}^{-1}$ indicates intensity reduction of these peaks; in addition, the changes in wavenumber of peaks in nanocamposite are compared to those of pure $\mathrm{n} \beta$ TCP. Therefore, it is supposed that P3HB polymer was connected to $\mathrm{n} \beta$-TCP surface by the phosphoric and hydroxyl groups (Figure 11(a)). In Figure 11(b), the carbonyl group absorption peak observed at $1725 \mathrm{~cm}^{-1}$ in pure polymer is sharper compared to the same peak in nanocomposite. Furthermore, this peak in $\mathrm{n} \beta$ -

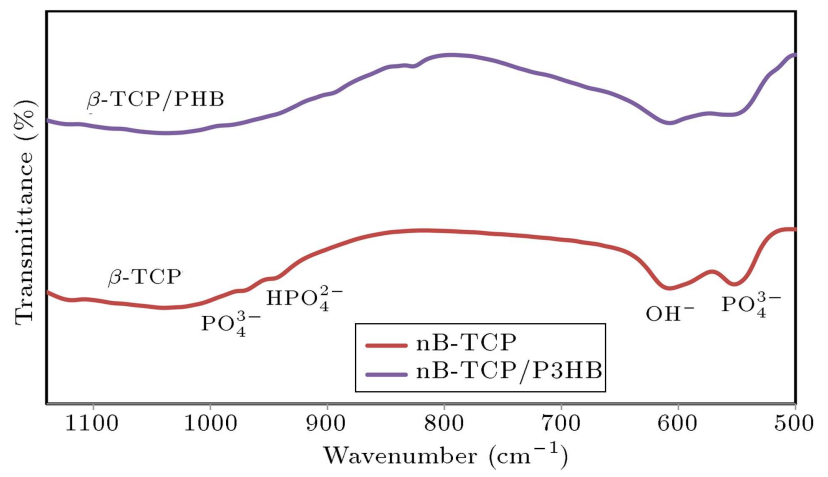

(a)

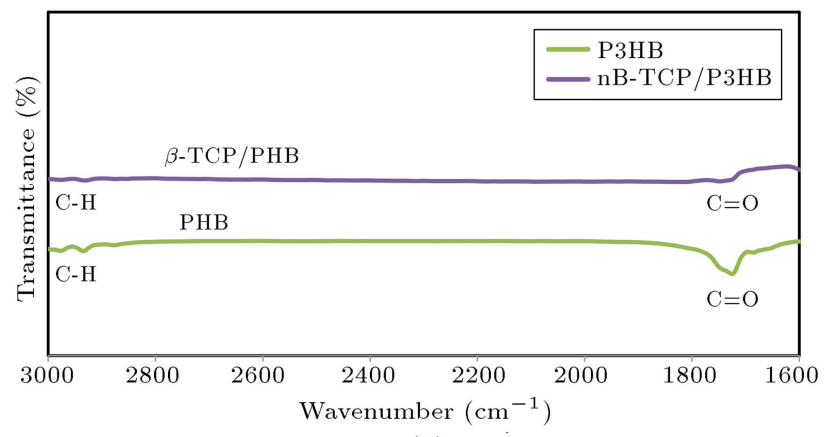

(b)

Figure 11. Pattern of FT-IR analysis: (a) n $\beta$-TCP and $\mathrm{n} \beta$-TCP/P3HB scaffolds and (b) P3HB polymer and $\mathrm{n} \beta$-TCP $/$ P3HB scaffold.

TCP/P3HB nanocomposite is shifted to a lower wave number up to $1721 \mathrm{~cm}^{-1}$, which possibly indicates hydrogen bond formation between P3HB carbonyl groups and $\mathrm{OH}$ groups of $\beta$-TCP particles. As previously mentioned, the twin peak observed in range of between 2874 and $2972 \mathrm{~cm}^{-1}$ is assigned to stretching aliphatic band of $\mathrm{C}-\mathrm{H}$ in pure polymer in which the same absorption band in the composite scaffold is observed with lower intensity in narrow range of wave number. The connection between the scaffold ceramic background and polymer molecules was confirmed by FTIR spectra [48].

\subsection{SEM of $n \beta-T C P$ scaffold with and without $P 3 H B$}

Figure 12(a) depicts the electron microscopic images of polyurethane foam with open pores in range of 300-700 $\mu \mathrm{m}$ before immersion in the ceramic slurry. Figure $12(\mathrm{~b})$ exposes porous $\mathrm{n} \beta$-TCP scaffold with pore diameters ranging from 200 to $600 \mu \mathrm{m}$. Figure 12(c) displays the micropores fabricated from $\mathrm{n} \beta$-TCP particles; these micropores promote tissue growth [20]. Figure $12(\mathrm{~d})$ shows porous $\mathrm{n} \beta$-TCP scaffold immersed in the polymer for $30 \mathrm{sec}$, and Figure 12(e) illustrates $\mathrm{n} \beta$-TCP scaffold immersed in the polymer for $60 \mathrm{sec}$. As observed in Figure 12, SEM images show uniform porosity in size 200 to $600 \mu \mathrm{m}$, which are appropriate for adhesion and migration of osteoblast cells [49]. 


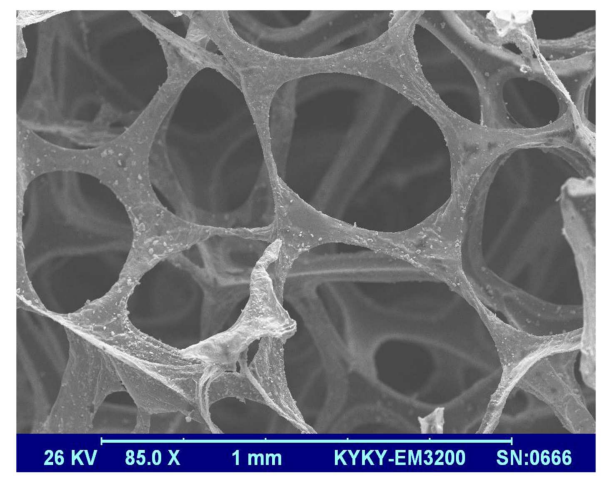

(a)

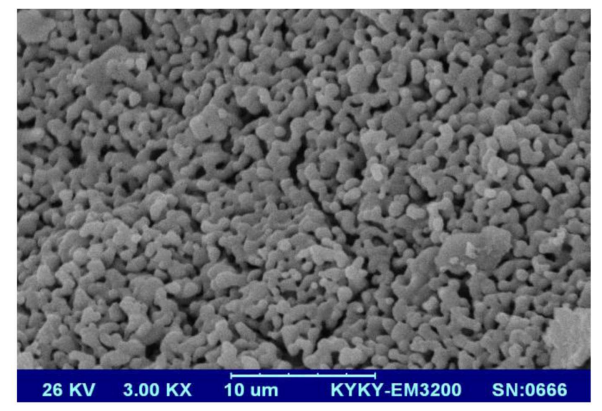

(c)

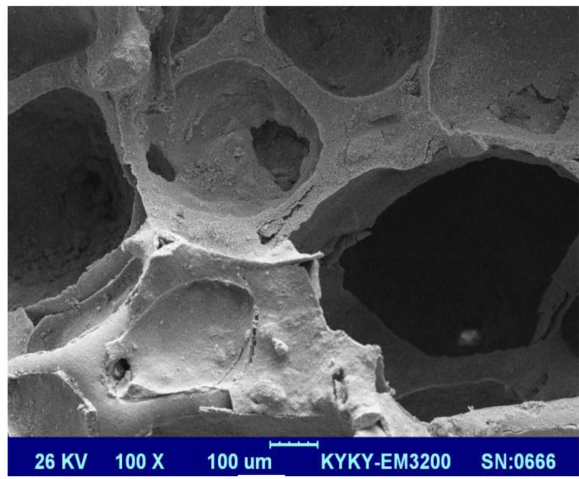

(b)

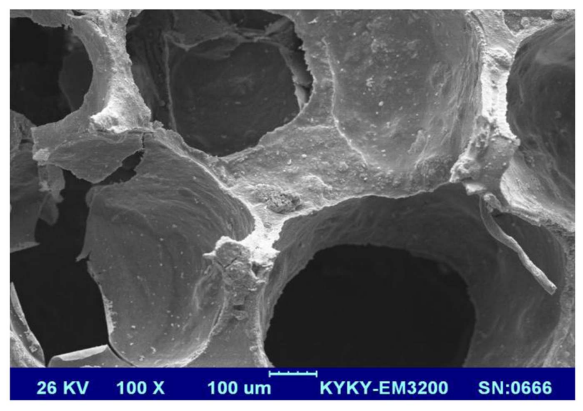

(d)

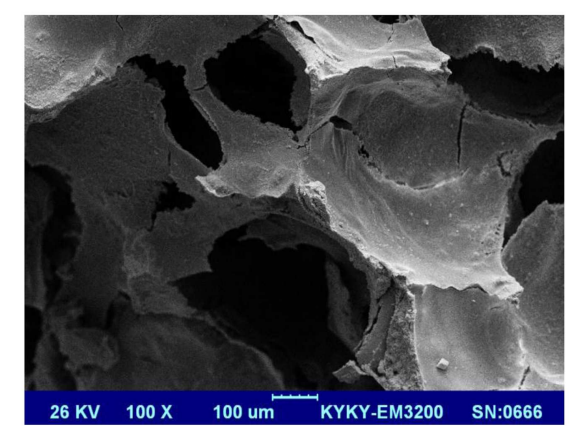

(e)

Figure 12. (a) Polyurethane sponge's image captured by SEM (85x). (b) Cross-section of n $\beta$-TCP scaffold. (c) View of micro-porosities' details $(3.00 \mathrm{kx}$ ). (d) Cross-section of $\mathrm{n} \beta$-TCP/P3HB scaffold for 30 sec. (e) n $\beta$-TCP/P3HB scaffold for 60 sec.

Miao et al. [38] reported HA/TCP composite scaffold porous structure with open macropores ranging from 300 to $700 \mu \mathrm{m}$ in diameter by the scanning electron micrograph observations. Also, Murphy et al. [49] evidenced the effect of scaffold pore size on cell attachment, induction, differentiation, proliferation, and migration in bone tissue engineering, and discovered that $325 \mu \mathrm{m}$ mean pore size is appropriate for bone tissue engineering scaffolds. Regarding Figure 12(d) and (e), it can be proved from these images that adding $\mathrm{P} 3 \mathrm{HB}$ to $\mathrm{n} \beta$-TCP ceramic scaffold and also the immersion time increase of scaffolds in the polymer decrease the porosity of scaffolds while maintaining a more interconnected porous structure which is beneficial for cells adhesion. Fabrication of pore interconnected porous structure is needed for the precise diffusion of nutrients and gases, such as oxygen, and for the removal of metabolic wastes resulted from the activity of migrated cells that had, meanwhile, grown into the porous scaffolds, thereby mimicking the cancellous bone structure $[11,50]$. Therefore, it is concluded that adding P3HB to $\beta$-TCP ceramic scaffold decreases the pore size of scaffolds, but it does not have harmful effect on them, because the scaffolds coated with a polymer have acceptable pore sizes for growing of bone cells, making them suitable candidates for bone replacement.

\subsection{Porosity measurements}

The porosity measurement was performed on $\mathrm{n} \beta$-TCP scaffolds with and without P3HB coating in 30 and 60 sec, and the porosity range was $70-84 \%$. The results of porosity percentages of the samples are shown in 
Table 2. Mean porosity of $\mathrm{n} \beta$-TCP scaffold with and without P3HB.

\begin{tabular}{cccc}
\hline Sample & $\begin{array}{c}\text { Porosity\% without } \\
\text { P3HB }\end{array}$ & $\begin{array}{c}\text { Coated P3HB } \\
\text { in 30 sec }\end{array}$ & $\begin{array}{c}\text { Coated P3HB } \\
\text { in 1 min }\end{array}$ \\
\hline$S_{1}{ }^{*}$ & $84 \pm 1$ & $77 \pm 1$ & $74 \pm 1$ \\
$S_{2}$ & $80 \pm 1$ & $75 \pm 2$ & $73 \pm 1$ \\
$S_{3}$ & $75 \pm 2$ & $72 \pm 1$ & $70 \pm 1$ \\
\hline
\end{tabular}

${ }^{*} S_{1}: 40 \% \beta$-TCP scaffold; $S_{2}: 50 \% \beta$-TCP scaffold; $S_{3}: 60 \% \beta$-TCP scaffold

Table 2. The results showed that with the increase of weight percentage of $\beta$-TCP, the porosity percentage was reduced. It is also concluded that adding $\mathrm{P} 3 \mathrm{HB}$ to $\mathrm{n} \beta$-TCP scaffolds decreased their porosity; this is despite the fact that it did not have adverse effect on the scaffolds, and it allowed the preservation of pores interconnection after infiltration process. According to the results of porosity measurements, it may be concluded that the samples immersed for $30 \mathrm{sec}$ in P3HB had higher porosity than the samples immersed for $1 \mathrm{~min}$ in P3HB. Mondal et al. [28] revealed that the porosity of Labeo rohita fish scale-derived scaffold was about 30-33\%. Kang et al. [37] determined that the porosity of $\beta$-TCP scaffold was about $82.49 \%$ and slightly declined up to $80.65 \%$ after PLGA infiltration. In a similar study, Chen et al. [51] demonstrated an about $2.2 \%$ devaluation in bio-glass macroporosity due to PDLA polymer coating. In addition, Miao et al. [38] proved that the total porosity of HA/TCP scaffolds was estimated to be up to $87 \%$ and indicated $\sim 2 \%$ macroporosity reduction due to coating and interpenetrating with the PLGA polymer. Furthermore, according to previous studies of Miao et al. [52,53], the removal of crack-like defects, owing to PLGA polymer phase filing into the open voids, was demonstrated. The crack-like defects of uncoated scaffolds caused the burning off of the PU sponge, initially centered with the ceramic particles [38]. Natural reduction of mechanical properties is brought about by the flaws such as cracks. Therefore, when the scaffolds after the polymer solution dipping were placed into centrifuge, the centrifugal effect caused the polymer to fill the crack-like defects [38].

\subsection{Compressive strength and compressive modulus of $n \beta-T C P$ scaffolds with and without $\mathrm{P} 3 \mathrm{HB}$}

Figure 13(a) shows representative stress-strain curve obtained in uni-axial tests performed on bare $\mathrm{n} \beta$ TCP scaffolds with various weight percentages of $\beta$ TCP ceramic. This figure illustrated that $\beta$-TCP failed in an elastic response of a brittle ceramic (i.e., within the linear region of the curve) obtained by disjointed rods that would collapse presumably by brittle fracture domination of struts [37]. The onset of the first of these cracks occurred during the elastic

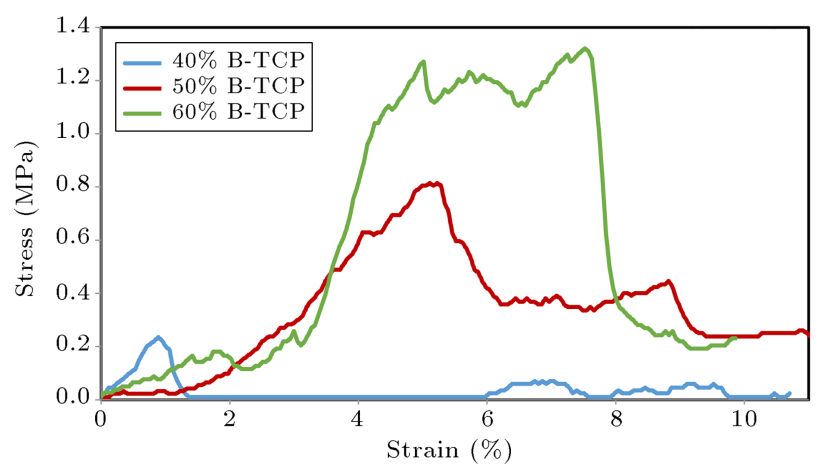

(a)

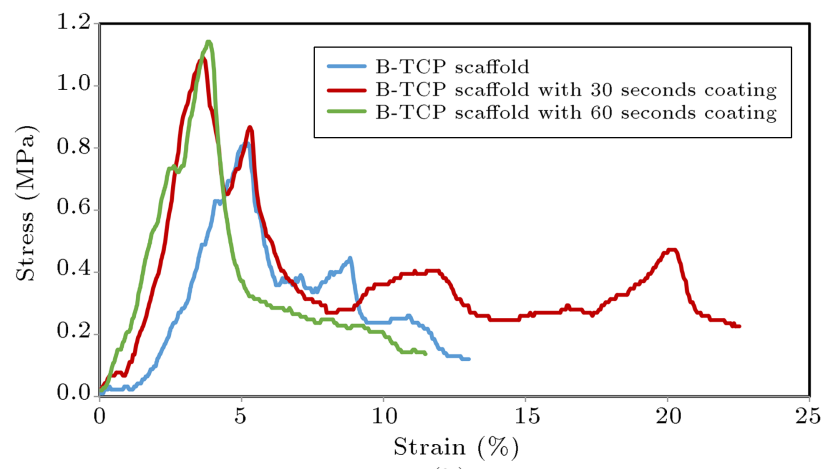

(b)

Figure 13. Stress-strain curves of compressive strength of ceramic scaffolds: (a) 40, 50 and 60 wt. $\%$ of bare $\mathrm{n} \beta$-TCP, and (b) 50 wt. $\%$ of n $\beta$-TCP uncoated, 50 wt. $\%$ of n $\beta$-TCP coated for $30 \mathrm{sec}$, and $50 \mathrm{wt} . \%$ of $\mathrm{n} \beta$-TCP coated for $60 \mathrm{sec}$.

regime (i.e., within the linear region of the curve) and was usually related to the maximum applied load, thereby determining the compressive strength of the scaffold [54]. It should be noted that compressive modulus of scaffolds is achieved by steep calculation of strain-stress curve in elastic regime. Based on the results, on one hand, compressive strength and compressive modulus of $\mathrm{n} \beta$-TCP scaffolds increased by the weight percentage increase of $\beta$-TCP; on the other hand, the porosity percentage decreased. The results of porosity percentage, compressive strength, and compressive modulus of uncoated and coated $\beta$ TCP scaffolds with various weight percentages are presented in Tables 2, 3, and 4, respectively. The compressive strength of a scaffold depends on its macroporosity, macro-pore size, macro-pore geometry, and the strength of the struts [38]. The compressive 
Table 3. Mean compressive strength of $\mathrm{n} \beta$-TCP scaffolds with and without P3HB $(P<0.05, n=3)$.

\begin{tabular}{|c|c|c|c|}
\hline Sample & $\begin{array}{c}\text { Without coat } \\
(\mathrm{MPa})\end{array}$ & $\begin{array}{c}\text { Coated P3HB } \\
\text { in } 30 \mathrm{sec}(\mathrm{MPa})\end{array}$ & $\begin{array}{l}\text { Coated P3HB } \\
\text { in } 1 \mathrm{~min}(\mathrm{MPa})\end{array}$ \\
\hline$S_{1}^{*}$ & $0.1727 \mp 0.0892$ & $0.6335 \mp 0.0460$ & $0.9872 \mp 0.0992$ \\
\hline$S_{2}$ & $0.5657 \mp 0.3524$ & $1.0901 \mp 0.21$ & $1.1419 \mp 0.4872$ \\
\hline$S_{3}$ & $1.0593 \mp 0.3691$ & $1.4276 \mp 0.2153$ & $1.59 \mp 0.6788$ \\
\hline
\end{tabular}

${ }^{*} S_{1}: 40 \% \mathrm{n} \beta$-TCP scaffold; $S_{2}: 50 \% \mathrm{n} \beta$-TCP scaffold; $S_{3}: 60 \% \mathrm{n} \beta$-TCP scaffold.

Table 4. Mean compressive modulus of $\mathrm{n} \beta$-TCP scaffolds with and without P3HB $(P<0.05, n=3)$.

\begin{tabular}{cccc}
\hline Sample & $\begin{array}{c}\text { Without coat } \\
\text { (MPa) }\end{array}$ & $\begin{array}{c}\text { Coated P3HB } \\
\text { in } \mathbf{3 0} \text { sec }(\mathbf{M P a})\end{array}$ & $\begin{array}{c}\text { Coated P3HB } \\
\text { in } \mathbf{1} \text { min }(\mathbf{M P a})\end{array}$ \\
\hline$S_{1}{ }^{*}$ & 16.13 & 20.06 & 27.603 \\
$S_{2}$ & 17.234 & 33.11 & 35.2 \\
$S_{3}$ & 17.7 & 49.593 & 63.51 \\
\hline
\end{tabular}

${ }^{*} S_{1}: 40 \% \mathrm{n} \beta$-TCP scaffold; $S_{2}: 50 \% \mathrm{n} \beta$-TCP scaffold; $S_{3}: 60 \% \mathrm{n} \beta$-TCP scaffold.

strength test was also performed on $\mathrm{n} \beta$-TCP scaffold with and without P3HB. The compression curves of bare $50 \% \beta$-TCP scaffold and PHB-coated $50 \% \beta$-TCP scaffolds for $30 \mathrm{sec}$ and $1 \mathrm{~min}$ were exhibited in Figure 13(b). The fracture phenomena also occurred in the coated scaffolds, but the curves indicated a significant increase of this linear elastic region range; moreover, the yield point substantially moved to a higher point, and this proves the improvement of strengthening after coating by polymer which is superior when compared with pure $\beta$-TCP scaffolds [37]. As seen in Tables 2 to 4 , the results achieved in the present study clearly showed that the mechanical performance of $\beta$-TCP scaffold can be enhanced remarkably by the incorporation of ductile polymer. In addition, they showed that with increasing immersion time of the polymer, the strength and modulus increased; by contrast, the porosity percentage decreased. This might explain that the mechanical behaviors of $\beta$-TCP scaffold improved by the substantial adhesion between $\beta$-TCP particles and PHB [19]. According to the achievements of Nalla et al. [55], the main toughening mechanism in bone was the crack bridging by the collagen polymer fibrils. The fracture surface showed the formation of fibrils which is related to that of collagen fibrils in cortical bone [55]. Therefore, it could be concluded that PHB polymer infiltration not only improved the mechanical strength of $\beta$-TCP ceramic scaffold, but also toughed $\beta$-TCP scaffold. Kang et al. [37] produced scaffolds from $\beta$ TCP coated with a PLGA polymer. The compressive strength of the scaffold before coating was $2.90 \mathrm{MPa}$ that increased to $1.44 \mathrm{MPa}$ by the interpenetration of PLGA. Miao et al. [38] also showed that by PLGA infiltration in HA/TCP, hybrid scaffolds increased their compressive strength up to $660 \mathrm{KPa}$. Bang et al. [19] exhibited that the compressive strength of $\alpha$-TCP foam increased from $30 \pm 10 \mathrm{kPa}$ to $750 \pm 20 \mathrm{kPa}$ when it was immersed in PCL polymer solution. Finally, to choose the most appropriate scaffold and compare it with regard to the obtained results from porosity percentage, compressive strength, and modulus, Table 5 was prepared. Based on the data available in these tables, the most proper scaffold for bioactivity and biodegradability tests can be selected. It should be noted that the suitable scaffold to use in tissue engineering and in studying bioactive and biodegradable behaviors should have porosity percent in range of 75$80 \%$, requiring compressive strength and modulus [56]. As seen in Table 5, $\beta$-tricalcium phosphate 40 wt. $\%$ scaffold has suitable porosity percent; by contrast, it has low compressive strength and modulus. Betatricalcium phosphate $60 \mathrm{wt} . \%$ scaffold has low porosity percent; by contrast, its compressive strength and modulus are high. Hence, according to the results of porosity percentage, compressive strength, and modulus shown in Table 5 , the most appropriate specimen for bioactive and biodegradable tests is $\beta$-tricalcium phosphate 50 wt.\% scaffold without and with PHB coating for $30 \mathrm{sec}$. The data of porosity, compressive and strength modulus for 50 wt. $\% \beta$-TCP scaffold are revealed and identified with highlights in this table.

\subsubsection{Statistical analysis for mechanical characterization}

As previously mentioned, results of compressive strength values related to $\mathrm{n} \beta$-TCP scaffold without and with P3HB for various weight percentages are shown in Table 3. According to statistical analysis, P-values for Scaffold without coating and scaffold with P3HB for 30 and $60 \mathrm{sec}$ are less than 0.05, and the assumed lack of difference is rejected. It means that, statistically, there is a significant difference between compressive strength of scaffold without coating and scaffold with P3HB for 30 and $60 \mathrm{sec}$. Furthermore, Since $P$-values 
Table 5. Porosity, compressive strength, and modulus of ceramic scaffold for 40, 50, and 60 wt. $\%$ of n $\beta$-TCP with and without $\mathrm{P} 3 \mathrm{HB}$ coating.

\begin{tabular}{ccccc}
\hline Type of scaffold & $\mathbf{n} \boldsymbol{\beta}$-TCP\% & Porosity\% & $\begin{array}{c}\text { Compressive } \\
\text { strength (MPa) }\end{array}$ & $\begin{array}{c}\text { Compressive } \\
\text { modulus (MPa) }\end{array}$ \\
\hline \multirow{2}{*}{$\beta$-Tricalcium phosphate } & 40 & 83.90 & 0.1727 & 16.13 \\
& $\mathbf{5 0}$ & $\mathbf{8 0 . 4 9}$ & $\mathbf{0 . 5 6 5 7}$ & $\mathbf{1 7 2 3 3 4}$ \\
& 60 & 74.56 & 1.0593 & 17.7 \\
With 30 sec coating & 40 & 76.84 & 0.6335 & 20.06 \\
& $\mathbf{5 0}$ & $\mathbf{7 5 . 3 1}$ & $\mathbf{0 . 9 0 1 9}$ & $\mathbf{3 3 . 1 1}$ \\
& 60 & 71.80 & 1.4276 & 43.593 \\
With 60 sec coating & 40 & 74 & 0.9872 & 27.603 \\
& 50 & 73.24 & 1.1419 & 35.2 \\
\hline
\end{tabular}

for Scaffold with various weight percentages are less than 0.05 , the assumed lack of difference is rejected. It means that, statistically, there is a significant difference between compressive strengths of $40 \%, 50 \%$, and $60 \%$ $\beta$-TCP scaffolds. In fact, confidence coefficient of this mechanical test is $95 \%$.

Similarly, the results of compressive modulus related to $\mathrm{n} \beta$-TCP scaffold without and with $\mathrm{P} 3 \mathrm{HB}$ for various weight percentages are shown in Table 4 . Since $P$-values for scaffold without coating and scaffold with P3HB coating for 30 and $60 \mathrm{sec}$ are less than 0.05 , the assumed lack of difference is rejected. It means that, statistically, there is a significant difference between compressive modulus of scaffold without coating and scaffold with $\mathrm{P} 3 \mathrm{HB}$ for 30 and $60 \mathrm{sec}$. In addition, since $P$-values for 40,50 , and $60 \mathrm{wt} . \%$ scaffolds are less than 0.05 , the assumed lack of difference is rejected. It means that, statistically, there is a significant difference between compressive modulus of $40 \% \beta$-TCP, $50 \% \beta$ TCP, and $60 \% \beta$-TCP scaffold. In fact, confidence coefficient of this mechanical test is $95 \%$.

\section{Conclusion}

In this research, $\beta$-TCP ceramic scaffold was constructed using a polymeric sponge method, and it was coated with P3HB. The results of FTIR, XRF, and XRD analyses confirmed the purity of fabricated $n \beta$ TCP powder by using the sol-gel method, and the results of TEM analysis emphasized that the particle size of $\mathrm{n} \beta$-TCP is about $50-70 \mathrm{~nm}$ and has irregular morphology. The findings of XRD and FTIR of scaffolds also proved the production of $n \beta$-TCP /P3HB composite scaffold. Porosity is a significant factor to design a scaffold. In fact, the production of scaffold with designed pore architecture is an essential request for bone tissue engineering. The results of SEM analysis and porosimetry indicated that adding P3HB to $\mathrm{n} \beta$ TCP scaffold resulted in a decrease in the amount of porosity, but the increase of size, volume, and interconnectivity of porosity was also maintained. The results of mechanical test showed that the increase of the weight percentage of $\beta$-TCP and adding P3HB to $\mathrm{n} \beta$-TCP scaffold brought about an increase in compressive strength and compressive modulus. In the end, according to the comparison of result collection of mechanical and porosimetry tests, it is evidenced that the optimal specimen was scaffold with $50 \mathrm{wt} \%$ of $\mathrm{n} \beta$-TCP and coating time of $30 \mathrm{sec}$ which has 1.09 $\mathrm{MPa}$ compressive strength, $33.11 \mathrm{MPa}$ compressive modulus, and $75 \%$ porosity. Therefore, this scaffold has a promising possibility to be applied as a bone filling substitution in tissue engineering field.

\section{References}

1. Greenwald, A.S. and Garino, J.P. "Bearing surfaces: The good, the bad and the ugly", Am. J. Bone. Joint Surg., 83, p. 98 (2001).

2. Mahendra, A. and Maclean, A.D. "Available biological treatments for complex non-unions Injury", Injury, 38, pp. S7-12 (2007).

3. Mattasi, F., Nistri, L., Chicon paez, D. and Innocenti, M. "New biomaterials for bone regeneration", Clin Cases in Mineral and Bone Metab., 8(1), pp. 21-24 (2011).

4. Finkemeier, C.G. "Current concept review: bonegrafting and bonegraftsubstitutes", J. Bone Joint Surg. Am., 84, pp. 454-564 (2002).

5. Keating, J.F. and McQueen, M.M. "Substitutes for autologous bone graft in orthopedic trauma", J. Bone. Joint Surg. Br., 83, pp. 3-8 (2001).

6. Dorozhkin, S.V. "Calcium orthophosphate-containing biocomposites and hybrid biomaterials for biomedical applications", J. Funct. Biomater., 6, pp. 708-832 (2015). 
7. Koc, N., Timucina, M. and Korkusuz, F. "Fabrication and characterization of porous tricalcium phosphate ceramics", Ceram. Int., 30, pp. 205-211 (2004).

8. Soleymani Eil Bakhtiyari1, S., Karbasi, S., Monshi, A. and Montazeri, M. "Evaluation of the effects of nano- $\mathrm{TiO}_{2}$ on bioactivity and mechanical properties of nano bioglass-P3HB composite scaffold for bone tissue engineering", J Mater Sci: Mater Med, 27(2), pp. 1-17 (2016).

9. Duan, B. and Wang, M. "Customized Ca-P/PHBV nanocomposite scaffolds for bone tissue engineering: design, fabrication, surface modification and sustained release of growth factor", J.R. Soc. Interface, 7, pp. S615-S629 (2010).

10. Sun, W. and Lal, P. "Recent development on computer aided tissue engineering - a review", Comput. Methods Programs Biomed., 67(2), pp. 85-103 (2002).

11. Mondal, B., Mondal, S., Mondal, A. and Mandal, N. "Fish scale derived hydroxyapatite scaffold for bone tissue engineering", Mater Charact., 121, pp. 112-124 (2016).

12. Kneser, U., Schaefer, D.J., Munder, B., Klemt, C., Andree, C. and Stark, G.B. "Tissue engineering of bone", Min. Invas. Ther. \& Allied Technol., 11, pp. 107-116 (2002).

13. Montazeri, M., Karbasi, S., Foroughi, M.R., Monshi, A. and Ebrahimi-kahrizsangi, R. "Evaluation of mechanical property and bioactivity of nano-bioglass 45S55 scaffold coated with poly-3-hydroxybutyrate", J. Mater Sci: Mater Med., 26(62) pp. 1-11 (2015).

14. Mondal, S., Mondal, B., Roy, S. and Guha, R. "Synthesis, characterization and in vitro cytotoxicity assessment of hydroxyapatite from different bioresources for...", Bull. Mater. Sci., 35(4), pp. 683-691 (2012).

15. Sun, F., Zhou, H. and Lee, J. "Various preparation methods of highly porous hydroxyapatite/polymer nanoscale biocomposites for bone regeneration", Acta Biomaterialia., 7, pp. 3813-3828 (2011).

16. Wagoner-Johnson, A.J. and Herschler, B.A. "A review of the mechanical behavior of $\mathrm{CaP}$ and $\mathrm{CaP} /$ polymer composites for applications in bone replacement and repair", Acta Biomater., 7, pp. 16-30 (2011).

17. Gerhardt, L.C. and Boccaccini, A.R. "Bioactive glass and glass-ceramic scaffolds for bone tissue engineering", Mater., 3, pp. 3867-3910 (2010).

18. Boccaccini, A.R., Blaker, J.J., Maquet, V., Day, R.M. and Je'rome, R. "Preparation and characterization of poly(lactide-co-glycolide) (PLGA) and PLGA/Bioglasss ${ }^{\circledR}$ composite tubular foam scaffolds for tissue engineering applications", Mater Sci Eng: C., 25, pp. 2523-31 (2005).

19. Bang, L.T., Tsuru, K., Munar, M., Ishikawa, K. and Othman, R. "Mechanical behavior and sell response of PCL Coated $\beta$-TCP foam for cancellous-type bone replacement", Ceram. Int., 39, pp. 5631-5637 (2013).

20. Foroughi, M.R., Karbasi S. and Ebrahimi-Kahrizsangi, R. "Physical and mechanical properties of a poly3-hydroxybutyrate coated nanocrystalline hydroxyapatite scaffold for bone tissue engineering", J. Porous Mater., 19, pp. 667-675 (2012).

21. Yu, H.S., Jin, G.Z., Won, J.E., Wall, I. and Kim, H.W. "Macrochanneled bioactive ceramic scaffolds in combination with collagen hydrogel: a new tool for bone tissue engineering", J. Biomed. Mater. Res A., 100(9), pp. 2431-2440 (2012).

22. Cortez, P.P., Silva, M.A., Santos, et al. "A glassreinforced hydroxyapatite and surgical-grade calcium sulfate for bone regeneration: In vivo biological behavior in a sheep model", J. Biomater. Appl., 27, pp. 201-217 (2012).

23. Santos, C.F.L., Silva, A.P., Lopes, L., Pires, I. and Correia, I.J. "Design and production of sintered $\beta$ tricalcium phosphate 3D scaffolds for bone tissue regeneration", Mater. Sci. Eng. C., 32(5), pp. 12931298 (2012).

24. Chen, T.M., Yao, C.H., Wang, H.J., Chou, G.H., Lee, T.W. and Lin, F.H. "Evaluation of a novel malleable, biodegradable osteoconductive composite in a rabbit cranial defect model", Mater. Chem. Phys., 55, pp. 4450 (1998).

25. Lin, k., Chen, L., Qu, H., Lu, J. and Chang, J. "Improvement of mechanical properties of microporous $\beta$-tricalcium phosphate bioceramic scaffolds with uniform and interconnected pore structures", Ceram. Int., 37, pp. 2397-2403 (2011).

26. Agrawal, C.M. and Ray, R.B. "Biodegradable polymeric scaffolds for musculoskeletal tissue engineering", J. Biomed. Mater. Res., 55(2), pp. 141-150 (2001).

27. Yang, S., Leong, K., Du, Z. and Chua, C.K. "The design of scaffolds for use in tissue engineering. Part I. Traditional factors", Tissue Eng., 7(6), pp. 679-689 (2001).

28. Mondal, S., Mondal, A., Mandal, N., Mondal, B., Mukhopadhyay, S., Dey, A. and Singh, S. "Physicochemical characterization and biological response of Labeo rohita-derived hydroxyapatite scaffold", Bioprocess Biosyst. Eng., 37, pp. 1233-1240 (2014).

29. Queiroz, A.C., Teixeira, S., Santos, J.D. and Monteiro, F.J. "Production of porous hydroxyapatite with potential for controlled drug delivery", Mater. Sci. Forum., 455, pp. 358-360 (2004).

30. Queiroz, A.C., Santos, J.D., Vilar, R., Eugénio, S. and Monteiro, F.J. "Laser surface modification of hydroxyapatite and glass-reinforced hydroxyapatite", Biomaterials, 25, pp. 4607-4616 (2004).

31. Teixeira, S., Ferraz, M.P. and Monteiro, F.J. "Biocompatibility of highly macroporous ceramic scaffolds: cell adhesion and morphology studies", J. Mater. Sci. Mater. Med., 19, pp. 855-859 (2008). 
32. Dorozhkin, S.V. "Calcium orthophosphate deposits: Preparation, properties and biomedical applications", Mater Sci Eng. C., 55, pp. 272-326 (2015).

33. Brodie, J.C., Goldie, E., Connel, G., Merry, J. and Grant, M.H. "Osteoblast interactions with calcium phosphate ceramics modified by coating with type I collagen", J. Biomed. Mater. Res. A, 73, pp. 409-421 (2005).

34. Chen, G.Q. and Wu, Q. "The application of polyhydroxyalkanoate as tissue engineering materials", Biomaterials, 26(33), pp. 6565-78 (2005).

35. Tan, 1., Yu, X., Wan, P. and Yang, K. "Biodegradable materials for bone repairs: A review", J. Mater. Sci. Technol., 29(6), pp. 503-513 (2013).

36. Linhart, W., Lehmann, W., Siedler, M., Peters, F., Schilling, A.F., Schwarz, K., Amling, M., Rueger, J.M. and Epple, M. "Composites of amorphous calcium phosphate and poly(hydroxybutyrate) and poly(hydroxybutyrate-co-hydroxyvalerate) for bone substitution: Assessment of the biocompatibility", $J$. Mater. Sci., 41, pp. 4806-4813 (2006).

37. Kang, Y., Scully, Young, A., Sungwoo, D.A. Helen, K., Sen, T. and Milan, S. "Enhanced mechanical performance and biological evaluation of a PLGA coated $\beta$ TCP composite scaffold for load-bearing application", Eur. Polym. J., 47, pp. 1569-1577 (2011).

38. Miao, X., Tan, D.M., Li, J., Xiao, Y. and Crawford, R. "Mechanical and biological properties of hydroxyapatite/tricalcium phosphate scaffolds coated with poly (lactic-co-glycolic acid)", Acta Biomater., 4, pp. 638645 (2008).

39. Sanosh, K.P., Chu, Cheol-Min, Balakrishnan, A., Kim, T.N. and Cho, S. "Sol-gel synthesis of pure nano sized $\beta$-tricalcium phosphate crystalline powders", Curr. Appl. Phys., 10, pp. 68-71 (2010).

40. Ramay, H. and Zhang, M. "Preparation of porous hydroxyapatite scaffolds by combination of the gelcasting and polymer sponge methods", Biomaterials, 24, pp. 3293-3302 (2003).

41. Filmon, R., Retailleau-Gaborit, N., Brossard, G., Grizon-Pascaretti, F., Basle, M.F. and Inserm, D.C. "MicroCT and preparation of $\beta$-TCP granular material by the polyurethane foam method", Image. Anal. Stereol., 28, pp. 103-112 (2009).

42. Chen, Q.Z., Thompson, I.D. and Boccaccini, A.R. "45S5 Bioglass-derived glass-ceramic scaffolds for bone tissue engineering", Biomaterials, 27, pp. 2414-2425 (2006).

43. Gao, C., Wei, P., Feng, P., Xiao, T., Shuai, C. and Peng, S. "Nano $\mathrm{SiO}_{2}$ and $\mathrm{MgO}$ improve the properties of porous $\beta$-TCP scaffolds via advanced manufacturing technology", Int. J. Mol. Sci., 16, pp. 6818-6830 (2015).

44. Kannan, S., Goetz-Neunhoeffer, F., Neubauer, J., Rebelo, A.H.S., Valério, P. and Ferreira, J.M.F. "Struc- ture and in vitro analysis on the influence of magnesium in biphasic (hydroxyapatite and $\beta$-tricalcium phosphate) mixtures", J. Biomed. Mater. Res. Part B: Appl Biomater, 90B(1), pp. 404-411 (2009).

45. Monshi, A., Foroughi, M.R. and Monshi, M.R. "Modified scherrer equation to estimate more accurately nano-crystallite size using XRD", World J. Nano Sci. Eng., 2(3), pp. 154-160 (2012).

46. Monshi, A., Quantitative Phase Analysis Industrial Research, ACXRI'96, pp. 40-46 (1998).

47. Rajabi-Zamani, A.H., Behnamghader, A. and Kazemzadeh, A. "Synthesis of nanocrystalline carbonated hydroxyapatite powder via nonalkoxide sol-gel method", Mater. Sci. Eng. C., 28, pp. 1326-1329 (2008).

48. Szubert, M., Adamaska, K., Szybowicz, M., Jesionowski, T., Buchwald, T. and Voelked, A. "The increase of apatite layer formation by the poly (3hydroxybutirate) surface modification hydroxyapatite and $\beta$-tricalcium phosphate", Mater. Sci. Eng. C., MSC-04237, pp. 1-9 (2013).

49. Murphy, C.M. and Brien, M.G. "The effect of mean pore size on cell attachment proliferation and migration in collagen glycosaminoglycan scaffolds for bone tissue engineering", Biomaterials, 31, pp. 461-466 (2010)

50. Soleymani Eli Bakhtiyari, S., Karbasi, S. and Monshi, A. "Evaluation of the effects of nano-TiO2 on physical and mechanical properties of nano-bioglass $45 \mathrm{~S} 5$ scaffold for bone tissue engineering", Scientia Iranica F, 22(3), pp. 1337-1345 (2015).

51. Chen, Q.Z. and Boccaccini, A.R. "Poly (D, L-lactic acid) coated 45S5 bioglass-based scaffolds: processing and characterization", J. Biomed. Mater. Res. A, 77(3), pp. 445-457 (2006).

52. Huang, X. and Miao, X. "Novel porous hydroxyapatite prepared by combining $\mathrm{H} 2 \mathrm{O} 2$ foaming with PU sponge and modified with PLGA and bioactive glass", $J$. Biomater. Appl., 21(4) pp. 351-374 (2007).

53. Miao, X., Tan, L.P., Tan, L.S. and Huang, X. "Porous calcium phosphate ceramics modified with PLGAbioactive glass", Mater. Sci. Eng. C., 27(2), pp. 274279 (2007).

54. Vázquez-Martínez, J.F., Perera, F.H., Miranda, P., Pajares, A. and Guibertea, F. "Improving the compressive strength of bioceramic robocast scaffolds by polymer infiltration", Acta Biomater., 6, pp. 43614368 (2010).

55. Nalla, R.K., Stölken, J.S., Kinney, J.H. and Ritchie, R.O. "Fracture in human cortical bone: local fracture criteria and toughening mechanisms", J. Biomech., $\mathbf{3 8}$, pp. 1517-1525 (2005).

56. Foroughi, M.R., Karbasi, S. and EbrahimiKahrizsangi, R. "Mechanical evaluation of nHAp scaffold coated with poly-3-hydroxybutyrate for bone tissue engineering", J. Biomed. Nanosci. Nanotechnol., 13, pp. 1555-1562 (2013). 


\section{Biogrphies}

Shabnam Shahi received her BS degree in CeramicMaterial Engineering from Shahreza Islamic Azad University, Iran, in 2011, and MS degree in CeramicMaterial Engineering from Shahreza Islamic Azad University, Iran, in 2015. She is currently pursuing research in tissue engineering.
Saeed Karbasi received his BS degree in Material Engineering from Shiraz University, Iran, in 1994 and MS and PhD degrees in Biomedical Engineering from Amirkabir University, Iran, in 1997 and 2005, respectively. He is currently an Associate Professor at Isfahan University of Medical Sciences, Iran. His research interests include biomaterials, tissue engineering, and nanobiomaterials. 